\title{
EFEITO NA BIOMECÂNICA DO JEJUNO DE CADÁVERES CANINOS PREPARADOS QUIMICAMENTE E EMBALADOS À VÁCUO VISANDO O ENSINO CIRÚRGICO
}

\author{
Giovana Carvalho Vieira ${ }^{1}$, Isabela Del Ponti², Geovana Coelho Ferreira ${ }^{3}$, e Fabrício \\ Singaretti de Oliveira ${ }^{4}$
}

1,2,3,4, Faculdade de Ciências Agrárias e Veterinárias, Universidade Estadual Paulista "Júlio de Mesquita Filho" (UNESP - Câmpus Jaboticabal)

DOI: $10.47094 /$ ICONRES.2021/25

Introdução: Com a expansão da ideologia que defende o bem-estar animal e sua não utilização em pesquisa e ensino, o emprego de cadáveres para o treinamento de cirurgia torna-se cada vez mais frequente. Assim, é necessário o uso de técnicas de conservação anatômica para evitar a deterioração e manter as propriedades físicas dos tecidos. Objetivo: Analisar, biomecanicamente, o jejuno de cadáveres de cães submetidos a tratamento químico, comparando com amostras de cadáveres frescos, sem qualquer tratamento. Metodologia: Foram selecionados oito animais (grupo 1), e foram colhidas três amostras de jejuno (amostras controle), que foram enviadas imediatamente para análise biomecânica. Foi então realizada a fixação, via artéria carótida comum, com solução contendo 120ml/ $\mathrm{kg}$ de sal cura, composta de $200 \mathrm{~g} / \mathrm{litro}$ de cloreto de sódio, $10 \mathrm{~g} / \mathrm{litro}$ de nitrito de sódio e $10 \mathrm{~g} / \mathrm{litro}$ de nitrato de sódio e em seguida, álcool etílico puro com 5\% de glicerina em relação ao volume do álcool, na quantidade de $150 \mathrm{ml} / \mathrm{kg}$ de peso corporal. Feito isso, cada cadáver foi colocado em saco plástico e embalado à vácuo por máquina profissional, sendo mantido refrigerado entre $0 \mathrm{e} 4^{\circ} \mathrm{C}$. Nos sete dias seguintes também se coletaram três segmentos jejunais para análise. Para o grupo 2, foram preparados mais oito cães e os graduandos avaliaram a qualidade dos cadáveres, utilizando-se escores ( 0 a 10) para maleabilidade, incisão e sutura do tecido. Resultados: Na estatística, apenas as amostras coletadas no dia 4 diferiram-se quanto a força máxima de ruptura. Quanto aos escores, houve diferença estatística na comparação com o cadáver fresco, mas os escores nunca foram inferiores a 7,35 $\pm 1,95$ e a aceitabilidade dos alunos foi de 100\%. Conclusões: A técnica anatômica foi efetiva para manter as características biomecânicas do jejuno por pelo menos 7 dias, o que é recomendado para o treinamento cirúrgico.

Palavras-chave: Anatomia. Cirurgia. Ensino.

Área temática: Medicina Veterinária 